\title{
Optimal plant density and nitrogen rates for improving off-season corn yields in Brazil
}

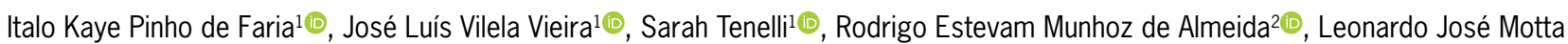

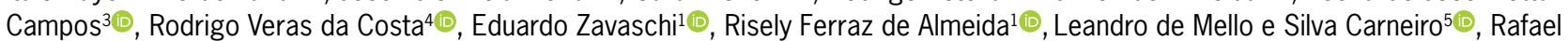
$\mathrm{Otto}^{1 *}$ (1)

${ }^{1}$ Universidade de São Paulo/ESALQ - Depto. de Ciência do Solo, Av. Pádua Dias, 11 - 13418-900 - Piracicaba, SP Brasil.

${ }^{2}$ Embrapa Pesca e Aquicultura, C.P. 90 - 77008-900 -

Palmas, TO - Brasil.

${ }^{3}$ Embrapa Soja, Rod. Carlos João Strass, s/n - 86001-970 Londrina, PR - Brasil.

${ }^{4}$ Embrapa Milho e Sorgo, Rod. MG-424, km 45 - 35701-970

- Sete Lagoas, MG - Brasil.

EUniversidade Federal de Uberlândia - Depto. de Solos, Av. Pará, 1720 - 38400-902 - Uberlândia, MG - Brasil.

*Corresponding author <rotto@usp.br>

Edited by: Francesco Montemurro

Received August 17, 2017

Accepted April 09, 2018
ABSTRACT: Integrating plant density and nitrogen (N) management is a strategy for improving corn yields, especially for off-season corn production in the tropics. This study tested the hypothesis that increasing plant densities and $\mathrm{N}$ rates promotes yield gains for off-season corn production in high-yielding environments. The aim of the study was to investigate the yield performances of two hybrid versions (DKB PRO and DKB PRO3) submitted to three plant densities (55,000; 65,000 and 75,000 plants ha-1) and four $\mathrm{N}$ rates (control, 60, 120 and $180 \mathrm{~kg} \mathrm{ha}^{-1} \mathrm{~N}$ ). Field trials were undertaken at Uberlândia-MG (site1 and 2) and Pedro Afonso-TO (site 3), Brazil from which data on corn yield parameters were collected and analyzed. Multivariate analysis separated the three trial areas into two groups, presenting high (sites 1 and 2) and low yields (site 3), which were related to weather conditions. There was no influence of a hybrid version or plant densities on crop yields at site 1 or 2 . In contrast, there was a positive response to increasing plant densities and the use of DKB PRO3 at site 3. A significant response to $\mathrm{N}$ was observed at sites 2 and 3 , following a plateau model. Our results suggest that $\mathrm{N}$ application rates and plant densities do have the potential to increase off-season corn yields in low yielding environments.

Keywords: Zea mays, hybrid, population, corn yield, second-crop

\section{Introduction}

Corn (Zea mays L.) can be cultivated as either an in-season (during summer) or off-season crop (during fall) in tropical regions. Currently, the off-season crop is the main production season in Brazil and contributes approximately $60 \%$ of total corn production $(\mathrm{CONAB}$, 2016). Due to the prevailing climate conditions, offseason corn crops typically suffer greater water deficit during the growing cycle, which can lower yields compared to the first season's crops (Soler et al., 2007).

The use of corn hybrids is one of the main strategies deployed to increase corn yields having widely shown increases of approximately $50 \%$ for adaptable hybrids (Gaffney et al., 2015). The spatial arrangement of plants (Penariol et al., 2003) and effective management of nitrogen $(\mathrm{N})$ fertilizers are other factors that can play a role in determining relative corn yield.

Plant density is directly related to intraspecific competition for environmental resources, such as solar radiation, water and nutrients (Dai et al., 2017). Nitrogen $(\mathrm{N})$ is one of the most important nutrients for corn development (O'Keeffe, 2009; Oliveira et al., 2018), responsible for improving the yield potential of the crop. Our understanding however, of the possible interactions between corn hybrids, plant density and $\mathrm{N}$ management for off-season crops in Brazil needs improving to ensure yield gains under the often challenging conditions of water limitation that occur during this growing season.

This study tested the hypothesis that increasing plant densities and $\mathrm{N}$ rates can promote yield gains for off-season corn production in high-yielding environments. Therefore, the aim of this study was to investigate the yield performance of two hybrid versions submitted to $\mathrm{N}$ application rates and plant densities during the off-season corn production.

\section{Materials and Methods}

\section{Characterization of sites}

The research was conducted during the 2016 growing season at two experimental areas in Uberlândia, Minas Gerais (site 1: $19^{\circ} 25^{\prime}$ S; $47^{\circ} 59^{\prime}$ W, altitude $700 \mathrm{~m}$; site 2: $18^{\circ} 59^{\prime} \mathrm{S} ; 48^{\circ} 07^{\prime} \mathrm{W}$; altitude $680 \mathrm{~m}$ ) and Pedro Afonso, Tocantins (site 3: $9^{\circ} 6^{\prime} \mathrm{S}, 48^{\circ} 8^{\prime} \mathrm{W}$, altitude $282 \mathrm{~m}$ ), Brazil (Figure 1).

The climate of Uberlândia, MG is classified as Cwa, humid subtropical zone, with dry winter and hot summer, according to the Köppen scale (Alvares et al., 2013), which is characterized by cold and dry winters (Apr to Sept) and hot, humid summers (Oct to Mar). The climate of Pedro Afonso, TO is classified as Aw, tropical, with dry winters, according to the Köppen scale (Alvares et al., 2013). Additionally, corn production in Pedro Afonso, TO, compared to Uberlândia, MG, has reduced yield potential due to the lower altitude, lower rainfall and greater variation in temperature between day and night.

Weather data were obtained from the meteorological stations located at each of the farms. The water balance was calculated according to Thornthwaite and Mather (1955) for each site using a water holding capacity (WHC) of $80 \mathrm{~mm}$ for all sites (Figure 2). Total rainfall 


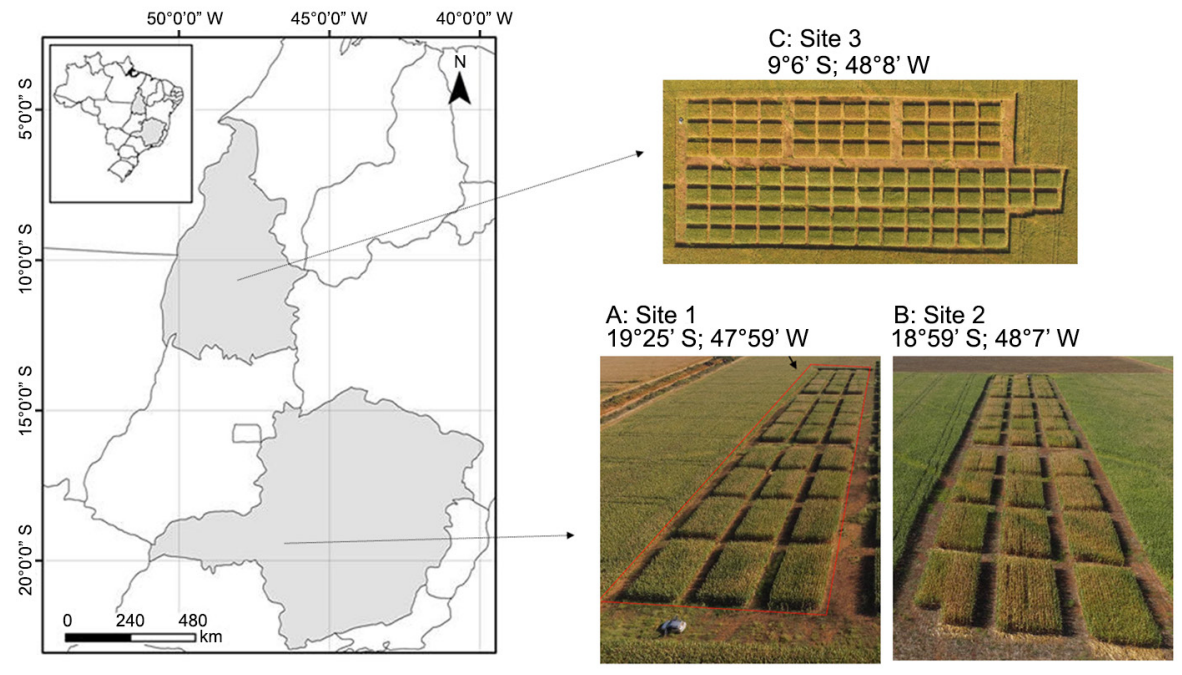

Figure 1 - Experimental sites in Uberlândia, MG (A: site 1; B: site 2) and Pedro Alfonso, TO (C: site 3).

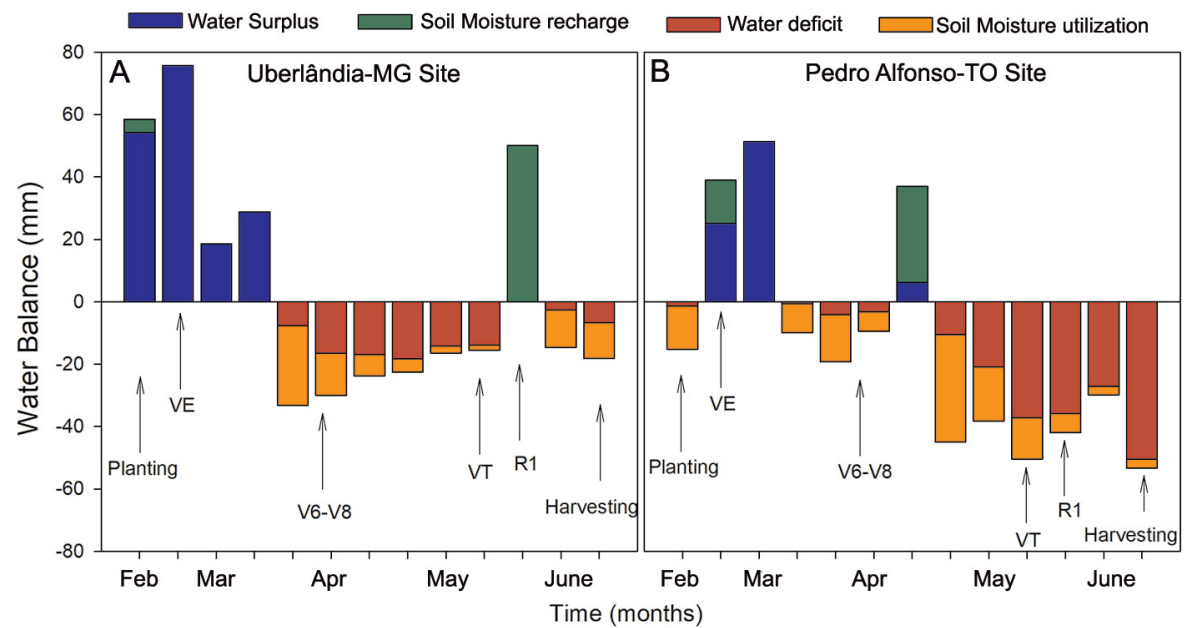

Figure 2 - Water balance during the agricultural year of 2016 in Uberlândia, MG (A: sites 1 and 2) and Pedro Alfonso, TO (B: site 3). In the graph, bar represent the mean of 10 days.

over the study period was 408.0 and $420.6 \mathrm{~mm}$, with means of 11.5 and 11.8 daylight hours, and daily mean temperature of $21.3^{\circ} \mathrm{C}$ and $27.3^{\circ} \mathrm{C}$ for sites $1 / 2$ and 3 , respectively.

The soils were classified as Oxisol (Typic Eutrudox) and clay (site 1) and sandy clay texture (site 2) in Uberlândia, MG; and Oxisol (Typic Hapludox) and sandy clay texture at Pedro Alfonso, TO (site 3) (Soil Survey Staff, 2014). Prior to the installation of trials, soil samples were collected from six positions (replication) within a depth range spanning the 0 to $1.0 \mathrm{~m}$ soil layer (i.e., $0.2 \mathrm{~m}$ depth intervals). Samples were homogenized before being submitted to analysis of chemical (Raij et al., 2001) and physical characteristics (Pipette method), Table 1.

\section{Experimental design}

The experiment involved the use of a split-splitplot design that included the treatments; two corn hybrid versions (DKB PRO and DKB PRO3); three plant densities $\left(55,000 ; 65,000\right.$, and 75,000 plants ha $\left.{ }^{-1}\right)$; and three $\mathrm{N}$ rates $\left(60,120\right.$, and $\left.180 \mathrm{~kg} \mathrm{ha}^{-1} \mathrm{~N}\right)$ plus a control (without N), each of which had three replicates per treatment. The trials were established at all three sites using the same experimental design.

The $\mathrm{N}$ source was urea $\left[\mathrm{CO}\left(\mathrm{NH}_{2}\right)_{2}\right]$ coated with the urease inhibitor NBPT (N-(n-butyl) triphosphoric triamide) to avoid volatilization losses. The fertilizer was applied by top dressing, without incorporation, at the V4 corn growth stage (i.e., four developed leaves). 
Table 1 - Soil characterization in Uberlândia, MG (sites 1 and 2) and Pedro Alfonso, T0 (site 3).

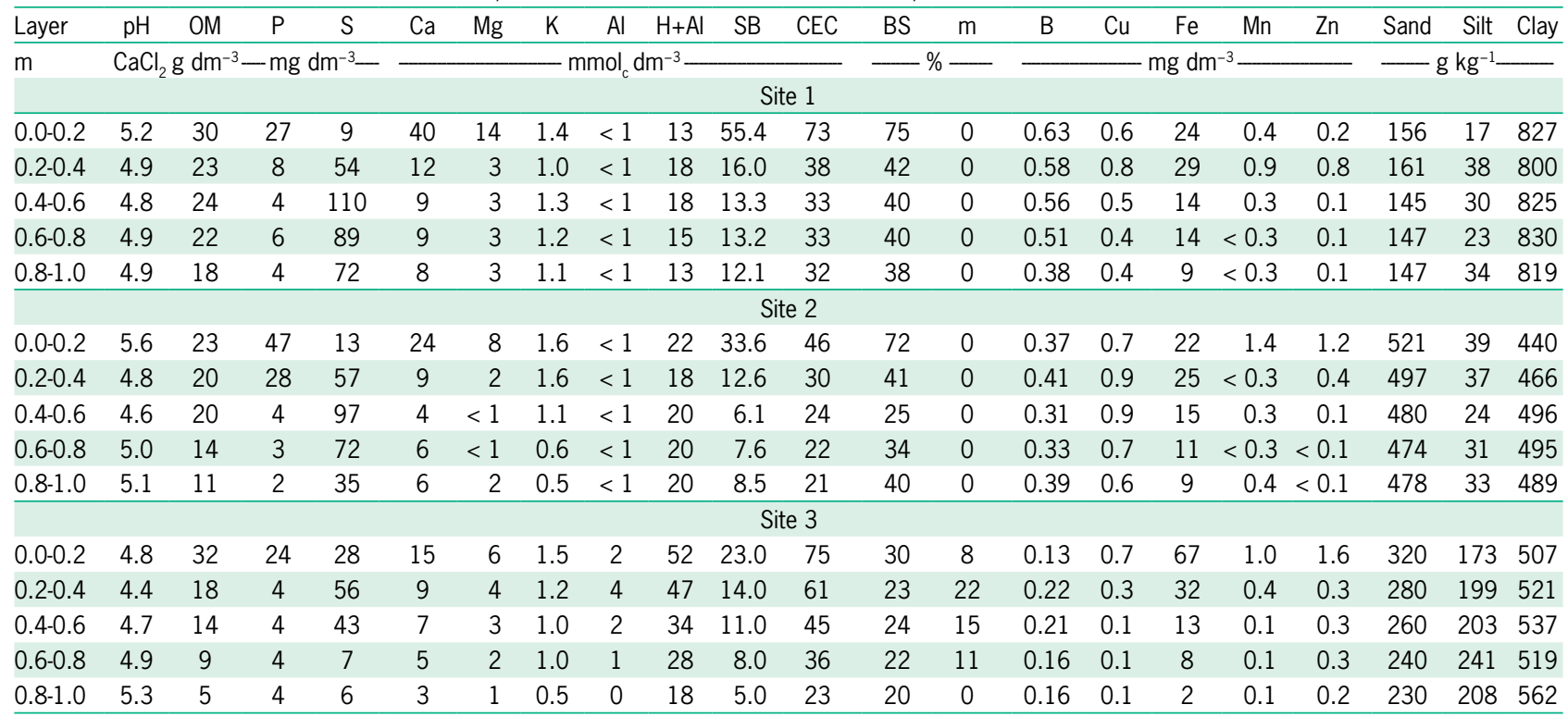

${ }^{1} \mathrm{pH}$ in $\mathrm{CaCl}_{2}\left(0.01 \mathrm{~mol} \mathrm{\textrm {L } ^ { - 1 }}\right) ; \mathrm{OM}=$ organic matter; $\mathrm{CEC}=$ cation exchange capacity; $\mathrm{BS}=$ base saturation; $\mathrm{m}=$ aluminum saturation.

Historically, sites 1 and 2 have been cultivated under a no-tillage system for 15 years with corn or soybean (Glycine max) as the first crop, and corn, wheat (Triticum sp.), oats (Avena sativa) or millet (Pennisetum americanum) as off-season crops in succession. Site 3 was cultivated with soybean and corn in succession for 15 years. Corn was sown using a no-tillage system (without soil disturbance) at all sites.

Neither lime nor gypsum were applied to any of the experimental areas following soil analysis (Table 1). Prior to planting, fertilizer was broadcast to supply $10 \mathrm{~kg}$ $\mathrm{ha}^{-1} \mathrm{~N}$ and $21 \mathrm{~kg} \mathrm{ha}^{-1} \mathrm{P}$ (Monoammonium phosphate $\mathrm{MAP}$ ); $50 \mathrm{~kg} \mathrm{ha}^{-1} \mathrm{~K}$ (Potassium chloride - $\mathrm{KCl}$ ); and 0.36 $\mathrm{kg} \mathrm{ha}{ }^{-1}$ of B (Ulexite).

The hybrids were sown on Feb $2^{\text {nd }}, 2016$ (Site 1 and 2) and Feb 25 desired plant densities of 55,65 and 75 thousand plants $\mathrm{ha}^{-1}$, sowing was done using an application rate of 2.75 ; 3.25 and 3.75 seeds per meter, respectively. The experimental units were composed of 10 lines of $15 \mathrm{~m}$ each in length and spaced at $0.5 \mathrm{~m}$.

The version DKB 290 VT PRO (VH 1) is an early hybrid (Bt technology), which has the advantages of controlling the main pests that attack corn (Spodoptera frugiperda, Diatraea saccharalis, and Helicoverpa zea). The DKB 290 VT PRO3 (VH2) is the same hybrid, but a slightly different version that also provides control for the main pests as well as Diabrotica speciose which has been shown to exhibit glyphosate tolerance (Pereira Filho and Borghi, 2016).

\section{Corn yield parameters analyzed}

Analysis of Soil-Plant Analyses Development (SPAD) was carried out using a chlorophyll meter to de- termine the SPAD index (Waskom et al., 1996). SPAD measurements were taken on 10 leaves per plot, using the first leaf below the corn ear at the R2 corn growth stage. The leaves analyzed were collected and subjected to $\mathrm{N}$ content determination according to the methods described in Malavolta et al. (1997).

Corn yield was assessed at the $\mathrm{R} 7$ growth stage (physiological maturity) through mechanized harvesting of the four central lines of the plots $(10 \mathrm{~m})$. The yield was estimated $\left(\mathrm{kg} \mathrm{ha}^{-1}\right)$, considering a standard moisture of $13 \%$ (wet basis). At site 3, the corn ear size (ES), number of grain rows per ear (NRE) and number of grains per ear (NGE) were also recorded at harvest time.

\section{Data processing and statistical analysis}

The variability in corn yield parameters was evaluated using both univariate and multivariate statistics, with the assumptions of normality (Shapiro-Wilk test) and homogeneity of variance (Bartlett test) validated prior to analysis. Hierarchical groupings and Principal Component Analysis (PCA) were used simultaneously as multivariate methods to analyze the variables from each experimental area. The data group was standardized to obtain a zero mean and constant variance (Sneath and Sokal, 1973). The Euclidean distance between data points were calculated and the Ward algorithm used to group similar data points according to the methods adopted by Hair (2010). The principal components (PC) with eigenvalues greater than 1 (which provides relevant information from the original variables) were used (Kaiser, 2002). PCA results were graphed to identify the groupings of information and hierarchical results were added to the PCA plots to visually highlight the relationships between variables and experimental areas. 
Yield parameters were assessed using analysis of variance (ANOVA) based on the F-test statistic. When the F-test was significant ( $p \leq 0.1)$, qualitative parameters (hybrids and plant densities) were compared using the LSD-test, while the quantitative parameter ( $\mathrm{N}$ rates) was analyzed through regression analysis and represented by Plateau model regression $(p \leq 0.1)$.

\section{Results}

\section{Principal component analysis}

The results of the PCA showed that the variables used in our study permit the separation of data into two distinct groups: group 1 comprised of sites 1 and 2, and group 2 (site 3) which was distinct from group 1 (Figure 3).

The variance in the PCA was concentrated along the PC1 axis and was able to explain $66 \%$ of variance, followed by PC 2 with $25 \%$. These components together accounted for $92 \%$ of the total variance. For all of the variables, the variance was strongly correlated with $\mathrm{PC} 1$, with correlation coefficient values higher than 70 $\%$. These correlation values are shown in Table 2 and are represented by vectors for each variable in Figure 3.

Sites 1 and 2 were represented by high-yielding corn production with means of $6,769 \pm 808$ and 6,231 $\pm 862 \mathrm{~kg} \mathrm{ha}^{-1}$, respectively. Site 3 showed comparatively lower levels of yield $\left(4,259 \pm 914 \mathrm{~kg} \mathrm{ha}^{-1}\right)$ and high SPAD values $(59.5 \pm 4.9)$. The yield vector was greater and closer to group 1, demonstrated by the strong association between group 1 and the yield vector. However, the SPAD vector was greater and closer to group 2 (Figure 3). The leaf $\mathrm{N}$ content vector was also related to group 2 , with higher overall values $(34.3 \pm 3.6)$ and increments of $26 \%$ and $30 \%$ when compared to sites 1 and 2 , respectively (Table 2). Interestingly, there was an inverse relationship between SPAD and leaf $\mathrm{N}$ content in terms of measures of corn yield, demonstrated

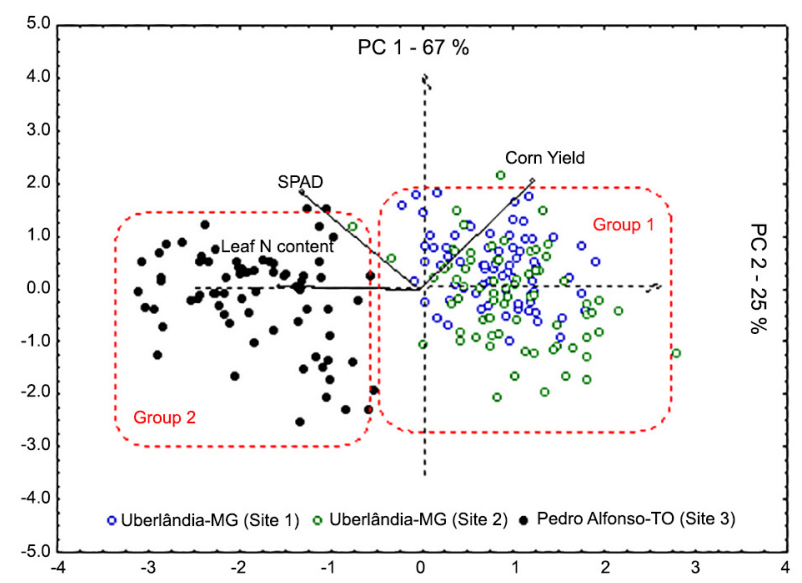

Figure 3 - Principal Component (PC) using the variables: SPAD, leaf nitrogen (N) content and corn yield in Uberlândia, MG (sites 1 and 2) and Pedro Alfonso, TO (site 3). by the opposite directions of the corn yield vector $(0.73)$ to those of leaf $\mathrm{N}$ content (-0.93) and SPAD (-0.78) (Table 2 and Figure 3).

\section{Corn yield parameters}

For site 1, only SPAD varied significantly in response to treatments (Table 3). The hybrid version VT PRO presented higher SPAD values than hybrid VT PRO3, while the increase in plant density reduced SPAD values. As expected, increasing $\mathrm{N}$ rates increased the SPAD values (Table 3), and fitted a quadratic response curve for each hybrid $\left(R^{2}=0.98\right.$ and $0.99 ; p \leq 0.1$ ) with maximum values given by the rates of 70.1 and $112.0 \mathrm{~kg} \mathrm{~N} \mathrm{ha}^{-1}$, respectively, for VT PRO

Table 2 - Correlation coefficients of the principal components (PC), mean of corn yield ( $\left.\mathrm{kg} \mathrm{ha}^{-1}\right), \mathrm{SPAD}$ and leaf nitrogen (N) content $\left(\mathrm{g} \mathrm{kg}^{-1}\right.$ ) at Uberlândia, MG (sites 1 and 2) and Pedro Alfonso, TO (site 3), Brazil.

\begin{tabular}{lccc}
\hline Factor & Corn yield & SPAD & Leaf N content \\
\hline & $\mathrm{kg} \mathrm{ha}^{-1}$ & & $\mathrm{~g} \mathrm{~kg}^{-1}$ \\
PC 1 & 0.73 & -0.78 & -0.93 \\
PC 2 & 0.65 & 0.58 & 0.03 \\
Site 1 & $6,769( \pm 808)$ & $53.3( \pm 3.5)$ & $25.4( \pm 2.7)$ \\
Site 2 & $6,231( \pm 862)$ & $51.1( \pm 4.8)$ & $24.1( \pm 2.6)$ \\
Site 3 & $4,259( \pm 914)$ & $59.5( \pm 4.9)$ & $34.3( \pm 3.6)$ \\
\hline
\end{tabular}

Correlations $(\geq 0.50)$ were considered highly significant in interpreting the principal component analysis. Values between brackets represent the standard deviation $(n=4)$.

Table 3 - SPAD, leaf nitrogen (N) content and corn yield as a function of hybrid versions, plant densities and $\mathrm{N}$ rates at site 1 .

\begin{tabular}{|c|c|c|c|}
\hline Treatments $^{1}$ & SPAD & Leaf $\mathrm{N}$ content & Corn yield \\
\hline & & $\mathrm{g} \mathrm{kg}^{-1}$ & $\mathrm{~kg} \mathrm{ha}^{-1}$ \\
\hline \multicolumn{4}{|c|}{ Hybrid version } \\
\hline DKB PRO & 53.9 a & 25.0 & 6,810 \\
\hline DKB PRO3 & $52.6 \mathrm{~b}$ & 25.7 & 6,728 \\
\hline \multicolumn{4}{|c|}{ Plant density $\left(10^{3} \mathrm{ha}^{-1}\right)$} \\
\hline 55 & $55.5 \mathrm{a}$ & 25.9 & 7,014 \\
\hline 65 & $52.7 \mathrm{~b}$ & 25.4 & 6,588 \\
\hline 75 & $51.6 \mathrm{c}$ & 24.7 & 6,706 \\
\hline \multicolumn{4}{|c|}{$\mathrm{N}$ rate $\left(\mathrm{kg} \mathrm{ha}^{-1}\right)$} \\
\hline 0 & 50.0 & 24.7 & 6,542 \\
\hline 60 & 53.1 & 24.7 & 6,607 \\
\hline 120 & 54.5 & 25.5 & 6,805 \\
\hline \multirow[t]{2}{*}{180} & 55.4 & 26.5 & 7,121 \\
\hline & \multicolumn{3}{|c|}{ ANOVA ( $p$ value) } \\
\hline$P_{\text {hybrid }}$ & $\leq 0.01$ & 0.293 & 0.659 \\
\hline$P_{\text {density }}$ & $\leq 0.01$ & 0.281 & 0.165 \\
\hline$P_{\text {Nrate }}$ & $\leq 0.01$ & 0.149 & 0.132 \\
\hline$P_{\text {hybridxdensity }}$ & 0.393 & 0.826 & 0.809 \\
\hline$P_{\text {hybrid } \times \text { Nrates }}$ & $\leq 0.01$ & 0.828 & 0.477 \\
\hline$P_{\text {density } x \text { Nrates }}$ & 0.543 & 0.721 & 0.380 \\
\hline$P_{\text {hybridxdensity } x \text { Nrat }}$ & 0.361 & 0.270 & 0.462 \\
\hline
\end{tabular}


and VT PRO3 (Figure 4). The values for leaf $\mathrm{N}$ content and corn yield were not influenced by treatments at site 1 (Table 3).

At site 2, there were clear reductions in both SPAD and leaf $\mathrm{N}$ content with increasing plant density (Table 4). However, such changes did not reflect yield losses, since yields were similar in the three plant densi-

Table 4 - SPAD, leaf nitrogen (N) content and corn yield as function of hybrid versions, plant densities and $\mathrm{N}$ rates at site 2 .

\begin{tabular}{|c|c|c|c|}
\hline Treatments $^{1}$ & SPAD & Leaf $\mathrm{N}$ content & Corn yield \\
\hline & & $\mathrm{g} \mathrm{kg}^{-1}$ & $\mathrm{~kg} \mathrm{ha}^{-1}$ \\
\hline \multicolumn{4}{|c|}{ Hybrid version } \\
\hline DKB PRO & 51.3 & 24.3 & 6,159 \\
\hline DKB PRO3 & 50.8 & 23.9 & 6,303 \\
\hline \multicolumn{4}{|c|}{ Plant density $\left(10^{3}\right.$ ha $\left.^{-1}\right)$} \\
\hline 55 & $51.6 \mathrm{a}$ & $25.0 \mathrm{a}$ & 6,217 \\
\hline 65 & $51.9 \mathrm{a}$ & $24.0 \mathrm{ab}$ & 6,314 \\
\hline 75 & $49.6 \mathrm{~b}$ & $23.2 b$ & 6,163 \\
\hline \multicolumn{4}{|c|}{$\mathrm{N}$ rate $\left(\mathrm{kg} \mathrm{ha}^{-1}\right)$} \\
\hline 0 & 45.6 & 23.1 & 5,492 \\
\hline 60 & 50.9 & 24.0 & 6,328 \\
\hline 120 & 53.0 & 25.3 & 6,559 \\
\hline \multirow[t]{2}{*}{180} & 54.6 & 23.9 & 6,546 \\
\hline & \multicolumn{3}{|c|}{ ANOVA ( $p$ value) } \\
\hline$P_{\text {hybrid }}$ & 0.530 & 0.560 & 0.452 \\
\hline$P_{\text {density }}$ & $\leq 0.01$ & $\leq 0.01$ & 0.807 \\
\hline $\mathrm{P}_{\text {Nrate }}$ & $\leq 0.01$ & $\leq 0.01$ & $\leq 0.01$ \\
\hline$P_{\text {hybridxdensity }}$ & 0.279 & 0.504 & 0.431 \\
\hline$P_{\text {hybridxNrates }}$ & 0.137 & 0.580 & 0.994 \\
\hline$P_{\text {density } \times \text { Nrates }}$ & 0.296 & 0.593 & 0.802 \\
\hline$P_{\text {hybridxdensity } \times N \text { rat }}$ & 0.927 & 0.851 & 0.437 \\
\hline
\end{tabular}

ties evaluated. In addition, there were no differences in SPAD, leaf $\mathrm{N}$ content and corn yield that was related to hybrid versions.

The increasing $\mathrm{N}$ rates increased the SPAD, leaf $\mathrm{N}$ content and corn yield at site 2 (Table 4), fitting a quadratic response curve for $\operatorname{SPAD}\left(\mathrm{R}^{2}=0.99 ; p \leq 0.1\right)$ and leaf $\mathrm{N}$ content $\left(\mathrm{R}^{2}=0.79 ; p \leq 0.1\right)$, and a linear-plateau model for corn yield $\left(\mathrm{R}^{2}=0.99 ; p \leq 0.1\right)$, which equated to the highest increment at $100.0 ; 75.1$ and $76.1 \mathrm{~kg} \mathrm{~N}$ ha $^{-1}$, respectively (Figures 4 and 5 ).

At site 3, the hybrid VT PRO3 presented higher SPAD, ES, NGE, and corn yield than hybrid VT PRO. The increase in plant density caused a reduction in NGE but increased corn yield. The other parameters were not modified by plant densities (Table 5). As expected, the increasing $\mathrm{N}$ rates had a direct positive effect on SPAD $\left(\mathrm{R}^{2}=0.97 ; p \leq 0.1\right)$ and leaf $\mathrm{N}$ content $\left(\mathrm{R}^{2}=0.91 ; p \leq\right.$ 0.1 , fitting quadratic response curves with maximum values given by rates of 140.1 and $166.6 \mathrm{~kg} \mathrm{~N}^{-1}$, respectively, (Figure 4; Table 5). The effect of $\mathrm{N}$ rate on corn yield fitted a linear-plateau model $\left(\mathrm{R}^{2}=0.83 ; p \leq\right.$ $0.1)$, showing gains that ranged between 0 and $60 \mathrm{~kg} \mathrm{~N}$ $\mathrm{ha}^{-1}$, but no yield gains above $60 \mathrm{~kg} \mathrm{ha}^{-1}$ of $\mathrm{N}$ (Figure 5 ; Table 5).

\section{Discussion}

\section{Principal component analysis}

Multivariate analysis such as PCA can be a useful tool for evaluating the effects of soil, weather and crop management on the yield of agricultural crops (Shukla et al., 2004; Zaidi et al., 2004; Govaerts et al., 2006; Tittonell et al., 2008). In our study, PCA was able to explain $92 \%$ of the variation in data, meeting the criteria of at least $70 \%$ as described by Senath and Sokal (1973).
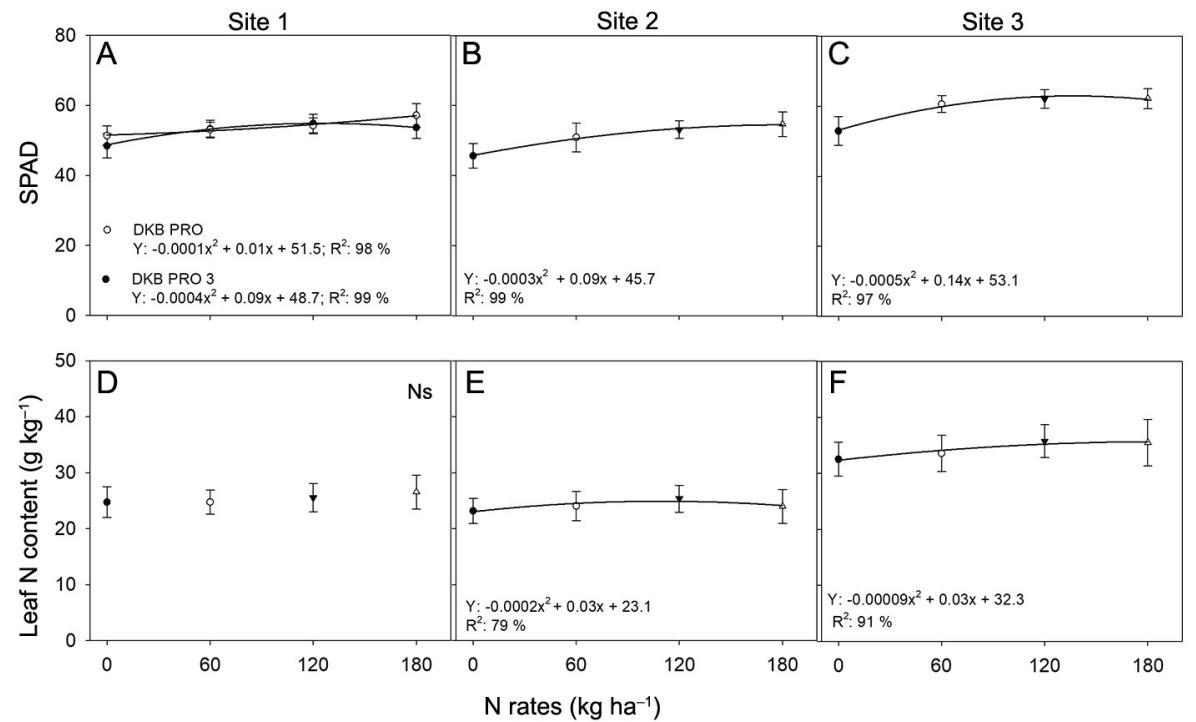

Figure 4 - Effect of $N$ rates on $\operatorname{SPAD}(A, B, C)$ and leaf nitrogen (N) content (D, E, F) in Uberlândia, MG (sites 1 and 2) and Pedro Alfonso, TO (site 3). Ns = not significant. 


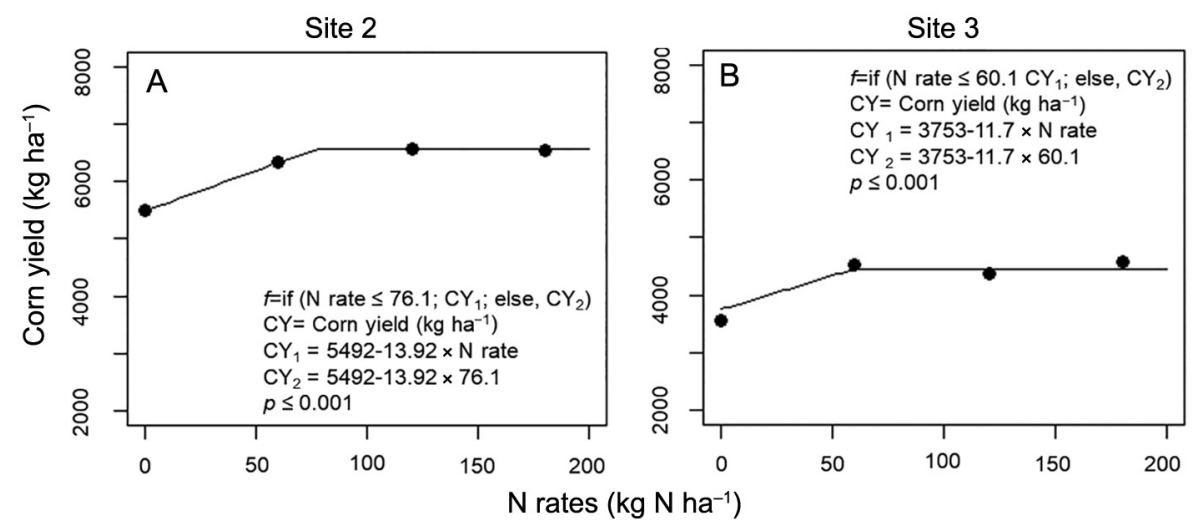

Figure 5 - Effect of nitrogen (N) rates on corn yield at Uberlândia, MG (A: site 2) and Pedro Alfonso, TO (B: site 3).

Table 5 - SPAD, leaf nitrogen (N) content, ear size (ES), number of grain row in ear (NRE), number of grains per ear (NGE), 1000 grains weight (1000-grains) and corn yield as a function of hybrid versions, plant densities and $\mathrm{N}$ rates at site 3.

\begin{tabular}{|c|c|c|c|c|c|c|c|}
\hline Treatments $^{1}$ & SPAD & $\mathrm{N}$ content & ES & NRE & NGE & 1000-grains & Corn yield \\
\hline & & $\mathrm{g} \mathrm{kg}^{-1}$ & $\mathrm{~cm}$ & & & g & $\mathrm{kg} \mathrm{ha}^{-1}$ \\
\hline \multicolumn{8}{|l|}{ Hybrid version } \\
\hline DKB PRO & $58.5 b$ & 33.9 & $14.2 \mathrm{~b}$ & 16.9 & $465.8 \mathrm{~b}$ & 295.1 & $4,055 b$ \\
\hline DKB PRO3 & $60.3 a$ & 34.7 & $14.9 \mathrm{a}$ & 17.0 & $488.3 \mathrm{a}$ & 289.8 & 4,461 a \\
\hline \multicolumn{8}{|c|}{ Plant density $\left(10^{3}\right.$ ha $\left.^{-1}\right)$} \\
\hline 55 & 60.2 & 35.0 & 14.8 & 17.0 & $491.8 \mathrm{a}$ & 291.0 & $3,721 \mathrm{c}$ \\
\hline 65 & 58.8 & 34.2 & 14.5 & 17.1 & $477.6 \mathrm{~b}$ & 295.0 & $4,280 \mathrm{~b}$ \\
\hline 75 & 59.3 & 33.8 & 14.5 & 16.8 & $461.8 \mathrm{c}$ & 291.3 & $4,774 a$ \\
\hline \multicolumn{8}{|l|}{$\mathrm{N}$ rate $\left(\mathrm{kg} \mathrm{ha}^{-1}\right)$} \\
\hline 0 & 52.9 & 32.5 & 14.2 & 16.7 & 445.1 & 305.1 & 3,569 \\
\hline 60 & 60.6 & 33.6 & 14.7 & 16.9 & 482.5 & 293.7 & 4,522 \\
\hline 120 & 62.1 & 35.7 & 14.6 & 17.0 & 485.9 & 291.4 & 4,373 \\
\hline \multirow[t]{2}{*}{180} & 62.2 & 35.5 & 14.8 & 17.2 & 495.1 & 279.5 & 4,569 \\
\hline & \multicolumn{7}{|c|}{ ANOVA ( $p$ value) } \\
\hline$P_{\text {hybrid }}$ & $\leq 0.01$ & 0.280 & $\leq 0.01$ & 0.67 & $\leq 0.01$ & 0.525 & $\leq 0.01$ \\
\hline$P_{\text {density }}$ & 0.235 & 0.478 & 0.519 & 0.471 & $\leq 0.01$ & 0.905 & $\leq 0.01$ \\
\hline$P_{\text {Nrate }}$ & $\leq 0.01$ & $\leq 0.01$ & 0.287 & 0.276 & $\leq 0.01$ & 0.197 & $\leq 0.01$ \\
\hline$P_{\text {hybridxdensity }}$ & 0.537 & 0.846 & 0.652 & 0.240 & 0.500 & 0.425 & 0.302 \\
\hline$P_{\text {hybrid } \times \text { Nrates }}$ & 0.853 & 0.553 & 0.960 & 0.260 & 0.275 & 0.332 & 0.501 \\
\hline$P_{\text {density } \times \text { Nrates }}$ & 0.341 & 0.369 & 0.353 & 0.743 & 0.444 & 0.241 & 0.283 \\
\hline$P_{\text {hybrid } x \text { density } x \text { Nrates }}$ & 0.316 & 0.437 & 0.933 & 0.763 & 0.507 & 0.277 & 0.953 \\
\hline
\end{tabular}

${ }^{1}$ Means followed by distinct letter in the column differ from each other by the LSD test $(p \leq 0.10)$.

Site differentiation into two distinct groups can be attributed mainly to differences in soil and weather conditions, which were reflected in the different corn yield parameters. The soil of site 3 presented lower base saturation within the soil profile and higher aluminum saturation, which can cause restriction in soil rooting within deeper soil layers and consequently lead to a reduction in yields (Caires et al., 2008), especially in environments that are subject to water stress.

The warm weather of site 3 , when compared to sites 1 and 2, is most probably another important driver of the higher yield potential observed. Lower temperature variation between day and night is an important factor that can determine corn yield. However, the most important factor likely to have limited the yield potential of site 3 was the severe drought conditions experienced by plants during the VT and R1 growth stages. The VT and R1 corn growth stages are considered to be the most sensitive to water stress (Lauer, 2008). The importance of water supply for corn yield has been extensively documented (Stiles, 1948; Lauer, 2008; Souza et al., 2015).

Interestingly, the values for SPAD and leaf $\mathrm{N}$ content were higher at site 3 (group 2) than they were at sites 1 and 2 (group 1). As expected, SPAD was positively correlated with leaf $\mathrm{N}$ content, but both showed an inverse relationship with corn yield. At sites 1 and 2, the excessive aboveground growth that resulted in yields ranging from $6,000-7,000 \mathrm{~kg} \mathrm{ha}^{-1}$, reduced the amount 
of $\mathrm{N}$ stored in plant tissue and possibly influenced the greenness of leaves when compared to site 3 . Such effects have been previously reported in a number of studies involving corn (Riedell, 2010; Schlegel and Havlin, 2017).

\section{Hybrid versions and plant densities}

The DKB-PRO version presented higher SPAD values than DKB-PRO3 at site 1, but an inverse pattern at site 3. SPAD evaluated the green intensity of leaves, which can be related to the $\mathrm{N}$ status of the plant during the crop cycle. Previous studies have similarly detected variation in SPAD among corn hybrids and cultivars (Yan et al., 2014).

The clear reduction in SPAD and leaf $\mathrm{N}$ content at site 2, which directly related to increased plant density, can be attributed to competition for nutrients, solar radiation and water (Penariol et al., 2003). The increase in plant density may have increased competition for $\mathrm{N}$, since higher SPAD values are related to improved $\mathrm{N}$ nutrition in plants. This effect can be confirmed if we consider the increases in SPAD and leaf $\mathrm{N}$ content associated with the increase in $\mathrm{N}$ rates observed at site 2 . However, the competition for $\mathrm{N}$ was probably limited since there were no yield losses associated with the increase in plant density at site 2 .

No gains in yield were achieved by increasing plant density for either site 1 or 2 . This outcome was not expected, since for both sites, the water stress was not considered intense during the growth cycle. The plants receiving the lower plant density treatment may have had better levels of development than those of the higher plant densities, justifying the same yields despite a reduction in the number of ears per area.

Site 3 might be considered a limiting environment for corn yield when compared to sites 1 and 2 . This site was the only one that presented differences between the hybrids and the plant density treatments. Use of the hybrid DKB-PRO3 resulted in higher SPAD, ES, NGE and yield values than DKB-PRO. Variation in corn yield between hybrids has been well documented (Penariol et al., 2003) and can be associated with differences in tolerance to drought, low-N conditions (Zaidi et al., 2004), and insect infestation (Pereira Filho and Borghi, 2016). A noteworthy difference between these two hybrid versions is that DKB-PRO3 is resistant to Diabrotica speciosa (worm-phase). This insect can cause damage to the root system and thereby reduce the capacity for absorbing water and nutrients (Pereira-Filho and Borghi, 2016).

Even under severe drought conditions which might have caused increased competition between plants at site 3, higher plant density increased yield, with differences varying from 560 to $1,053 \mathrm{~kg} \mathrm{ha}^{-1}$ compared to plant densities of 65,000 and 75,000 plants ha $^{-1}$, respectively. This result is in concordance with Dong et al. (2010), who described that in low fertility fields, any plant density increases can directly drive higher yields.
Interestingly, there was no reduction in ES, NRE, nor 1000-grain weight associated with increased plant density, suggesting that this did not exacerbate the water deficit suffered by plants in the denser treatments of 65,000 and 75,000 plants ha $^{-1}$. However, there was a reduction in NGE for these treatments, which can be explained by the drought that occurred during the flowering period (VT) that typically reduces the number of grains (Araus et al., 2012). The number of ears per hectare in the treatments with higher plant density probably compensated for the lower NGE and thus explains the yield increases observed.

According to Ren et al. (2016), the maximum corn yield for dry and normal years is obtained by using a plant density between 52,500 and 67,500 plants ha-1. In Brazil, it is common for growers to increase plant density during the first corn crop, because, in general, it is subjected to less water deficit, but density for the off-season crop as evaluated in the present study is often reduced. However, the results obtained from site 3 contradict the negative effect of density increase in the off-season. Site 3 is located in a warm region of Brazil, and increasing plant density can result in less solar radiation reaching the soil surface, which in turn reduces water evaporation. Unfortunately, we did not measure soil temperature in the present study and we were thus not able to explore this hypothesis.

Defining the optimal plant density depends on the characteristics of each hybrid (Penariol et al., 2003) as well as the soil and climate conditions (Dong et al. 2010). The density of 55,000 plants ha $^{-1}$ is frequently used by farmers in high-yielding corn systems in Brazil. However, higher plant densities, ranging from 65,000 to 80,000 plants ha ${ }^{-1}$, have been shown to produce higher yields for specific hybrids compared to lower plant densities (Penariol et al., 2003). The results of our study contradict the general idea that lower densities should be preferentially used in lower-yielding environments.

\section{Nitrogen rates}

Corn usually exhibits a high responsiveness to the addition of $\mathrm{N}$ (Yan et al., 2014; Oliveira et al., 2018). Indeed, sites 2 and 3 were responsive to $N$, but this same trend was not observed for site 1 . The lack of response at this site can be related to soil $\mathrm{N}$ mineralization of soil organic matter (SOM) (Cassman et al., 2002), either from the soil or residues of previously grown soybean (Puntel et al., 2016). In addition, the soil at site 1 presented adequate chemical conditions for root growth, allowing for extensive development through the soil profile and the subsequent absorption of $\mathrm{N}$ stored in the SOM. Although most studies show corn exhibits a response to $\mathrm{N}$ fertilization, this is not always the case as has been demonstrated by Khan et al. (2001).

Sites 2 and 3 presented a marked response to $\mathrm{N}$ fertilization with increases in corn yield through the addition of 76 and $60 \mathrm{~kg} \mathrm{~N}^{-1}$, respectively. Plants from site 2 experienced weather conditions that were similar 
to those grown at site 1 . However, the storage of SOM is considerably lower at site 2 , which explains the positive response to $\mathrm{N}$ observed only at this site. At site 3 , there was a response to $\mathrm{N}$ despite the severe drought conditions experienced by plants during the VT and R1 growth stages. Water stress during the cultivation of off-season crops in Brazil is common (Amado and Eltz, 2008) and may have limited the response to applied N observed for site 3 .

There was no interaction between $\mathrm{N}$ rates and plant densities for any of the sites evaluated. This finding indicated that increasing $\mathrm{N}$ rates in fields with reduced plant population, or increasing plant population but reducing $\mathrm{N}$ rates is not feasible for improving offseason corn production. This trend contradicts Dong et al. (2012), who found that cotton yield could be maximized using low plant density at a high $\mathrm{N}$ rate or high plant density at any $\mathrm{N}$ rate. Considering that cultivation of off-season corn is expanding in the tropics with limited scientific validation of best management practices, further studies are required to provide insights into the interaction between plant density and $\mathrm{N}$ rates on this production system.

\section{Conclusion}

In conclusion, our study suggests that the viability of increasing the corn yield potential of off-season crops may be limited by the conditions of low water. Our initial hypothesis was that increasing plant densities and $\mathrm{N}$ rates would result in yield gains in high-yielding environments. However, in contrast to initial expectations, there was no interaction between $\mathrm{N}$ rates and plant density for any of the sites evaluated.

According to the multivariate analysis, sites 1 and 2 can be categorized as high-yielding, while site 3 presents a low-yielding environment for off-season corn production. Water availability appears to be the primary factor driving differences in yield potential between sites.

Maximum yields were obtained using 60 and 76 $\mathrm{kg} \mathrm{N} \mathrm{ha}{ }^{-1}$ at sites 2 and 3, respectively indicating that a limitation of water can directly limit the $\mathrm{N}$ response of off-season corn production. In contrast to our expectations, increasing the density of plant stands may prove an effective management strategy for improving offseason corn yields in the low-yielding environment of site 3. Overall, our results suggest that $\mathrm{N}$ rates and plant densities have the potential to increase off-season corn yields for low yielding environments.

\section{Acknowledgments}

The Grupo de Apoio a Pesquisa e Extensão (GAPE), Agroindustrial Eldorado S.A. and the Empresa Brasileira de Pesquisa Agropecuária (EMBRAPA) for their support. $\mathrm{R}$ Otto received a research productivity fellowship from the Conselho Nacional de Desenvolvimento Científico e Tecnológico (CNPq; grant \#308007/2016-6).

\section{Authors' Contributions}

Conceptualization: Otto, R.; Faria, I.K.P.; Vieira, J.L.V; Almeida, R.E.M.; Campos, L.J.M.; Costa, R.V.; Zavaschi, E.; Silva Carneiro, L.M. Data acquisition: Faria, I.K.P.; Almeida, R.E.M.; Campos, L.J.M.; Costa, R.V.; Zavaschi, E., Silva Carneiro, L.M. Data analysis: Almeida, R.F.; Otto, R.; Tenelli, S. Design of Methodology: Otto, R.; Vieira, J.L.V; Almeida, R.E.M.; Campos, L.J.M.; Costa, R.V. Writing and editing: Almeida, R.F.; Otto, R., Tenelli, S.; Almeida, R.E.M.; Zavaschi, E.

\section{References}

Alvares, C.A.; Stape, J.L.; Sentelhas, P.C.; Gonçalves, J.L.M.; Sparovek, G. 2013. Köppen's climate classification map for Brazil. Meteorologische Zeitschrift 22: 711-728.

Amado, T.J.C.; Eltz, F.L.F. 2008. Nitrogen management in southern Brazil and western Paraguay, p. 124-143. In Hatfield, J.L.; Follett, R.F., eds. Nitrogen in the environment: sources, problems, and management. 2ed. Elsevier, New York, NY, USA.

Araus, J.L.; Serret, M.D.; Edmeades, G.O. 2012. Phenotyping maize for adaptation to drought. Front Physiology 3: 305.

Caires, E.F.; Garbuio, F.J.; Churka, S.; Barth, G.; Correa, J.C.L. 2008. Effects of soil acidity amelioration by surface liming on no-till corn, soybean, and wheat root growth and yield. European Journal of Agronomy 28: 57-64.

Cassman, K.G.; Dobermann, A.; Walters, D.T. 2002. Agroecosystems, nitrogen-use efficiency, and nitrogen management. Ambio 31: 132-140.

Companhia Nacional de Abastecimento [CONAB]. 2016. Monitoring of the Brazilian grain harvest. Third survey. = Acompanhamento da safra brasileira de grãos. Terceiro levantamento, Brasília, Brazil (in Portuguese). Available at: https://www.conab.gov.br. [Accessed Jan 14, 2018] (in Portuguese).

Dai, J.; Li, W.; Zhang, D.; Tang, W.; Li, Z.; Lu, H.; Kong, X.; Luo, Z.; Xu, S.; Xin, C.; Dong, H. 2017. Competitive yield and economic benefits of cotton achieved through a combination of extensive pruning and a reduced nitrogen rate at high plant density. Field Crops Research 209: 65-72.

Dong, H.; Li, W.; Enejia, A.E.; Zhang, D. 2012. Nitrogen rate and plant density effects on yield and late-season leaf senescence of cotton raised on a saline field. Field Crops Research 126: $137-144$

Dong, H.; Kong, X.; Li, W.; Tang, W.; Zhang, D. 2010. Effects of plant density and nitrogen and potassium fertilization on cotton yield and uptake of major nutrients in two fields with varying fertility. Field Crops Research 119: 106-113

Gaffney, J.; Schussler, J.; Löffler, C.; Cai, W.; Paszkiewicz, S.; Messina, C.; Groeteke, J.; Keaschall, J.; Cooper, M. 2015. Industry scale evaluation of maize hybrids selected for increased yield in drought stress conditions of the U.S. corn belt. Crop Science 55: 1608-1618.

Govaerts, B.; Sayre, K.D.; Deckers, J. 2006. A minimum data set for soil quality assessment of wheat and maize cropping in the highlands of Mexico. Soil Tillage Research 87: 163-174. 
Hair, J. 2010. Multivariate Data Analysis. Pearson, Hoboken, NJ, USA.

Khan, S.A.; Mulvaney, R.L.; Hoeft, R.G. 2001. A simple soil test for detecting sites that are nonresponsive to nitrogen fertilization. Soil Science Society of America Journal 65: 17511760.

Kaiser, K.; Eusterhues, K.; Rumpel, C.; Guggenberger, G.; Knabner, K. I. 2002. Stabilization of organic matter by soil minerals investigations of density and particle-size fractions from two acid forest soils. Journal of Plant Nutrition and Soil Science 165: 451-459.

Lauer, J. 2008. The effects of drought and poor corn pollination on corn. Field Crops Research 28: 493-495.

Malavolta, E.; Vitti, G.C.; Oliveira, S.A. 1997. Evaluation of the Nutritional Status of Plants: Principles and Applications = Avaliação do Estado Nutricional de Plantas: Princípios e Aplicações. POTAFOS, Piracicaba, SP, Brazil (in Portuguese).

O'Keeffe, K. 2009. Maize growth \& development. NSW Department of Primary Industries, Sydney, Australia. Available at: http://www.dpi.nsw.gov.au/_data/assets/pdf_ file/0007/516184/Procrop-maize-growth-and-development.pdf. [Accessed Mar, 2017]

Oliveira, S.M.; Almeida, R.E.M.; Ciampitti, I.A.; Pierozan Junior, C.; Lago, B.C.; Trivelin, P.C.O.; Favarin, J.L. 2018. Understanding $\mathrm{N}$ timing in corn yield and fertilizer $\mathrm{N}$ recovery: an insight from an isotopic labeled-N determination. Plos One 13: e0192776.

Penariol, F.G.; Fornasieri Filho, D.; Coicev, L.; Bordin, L.; Farinelli, R. 2003. Performance of maize cultivars sown in different row widths and population densities in off-season cultivation. Revista Brasileira de Milho e Sorgo 2: 52-60 (in Portuguese, with abstract in English).

Pereira Filho, I.A.; Borghi, E. 2016. Corn Seed Market in Brazil: Harvest 2016/2017 = Mercado de Sementes de Milho no Brasil: Safra 2016/2017. Embrapa Milho e Sorgo, Sete Lagoas, MG, Brazil. (Embrapa Milho e Sorgo Documentos, 28) (in Portuguese).

Puntel, L.A.; Sawyer, J.E.; Barker, D.W.; Dietzel, R.; Poffenbarger, H.; Castellano, M.J.; Archontoulis, S.V. 2016. Modeling longterm corn yield response to nitrogen rate and crop rotation. Frontiers in Plant Science 7: 1630.

Raij, B. van; Andrade, J.C.; Cantarella, H.; Quaggio, J.A. 2001. Chemical Analysis for Fertility Assessment of Tropical Soils. = Análise Química para Avaliação da Fertilidade de Solos Tropicais. Instituto Agronômico, Campinas, SP, Brazil (in Portuguese).

Ren, X.; Sun, D.; Wang, Q. 2016. Modeling the effects of plant density on maize productivity and water balance in the Loess Plateau of China. Agricultural Water Management 171: 40-48.
Riedell, W.E. 2010. Mineral-nutrient synergism and dilution responses to nitrogen fertilizer in field-grown maize. Journal of Plant Nutrition and Soil Science 173: 869-874.

Schlegel, A.J.; Havlin, J.L. 2017. Corn yield and grain nutrient uptake from 50 years of nitrogen and phosphorus fertilization. Agronomy Journal 109: 335-342.

Shukla, M.K.; Lal, R.; Ebinger, M. 2004. Principal component analysis for predicting corn biomass and grain yields. Soil Science 169: 215-224.

Sneath, P.H.; Sokal, R.R. 1973. Numerical taxonomy: the principles and practice of numerical classification. Freeman, San Francisco, CA, USA.

Soler, C.M.T.; Hoogenboom, G.; Sentelhas, P.C.; Duarte, A.P. 2007. Impact of water stress on maize grown off-season in a subtropical environment. Journal of Agronomy and Crop Science 193: 247-261.

Souza, L.C.; Nogueira, G.A.S.; Almeida, R.F.; Souza, L.C.; Galvão, M.; Oliveira Neto, C.F.; Oliveira, T.B.; Matos Viégas, I.J.; Okumura, R.S. 2015. Application of multivariate analysis to evaluate the biochemical changes in sorghum (Sorghum bicolor L. Moench) after exposure to water stress and silicon applications. African Journal of Biotechnology 14: 3257-3263.

Stiles, I.E. 1948. Relation of water to t1ie germination of corn and cotton seeds. Plant Physiology 23: 201-222.

Thornthwaite, C.W.; Mather, J.R. 1955. The Water Balance. Drexel Institute of Technology, Philadelphia, PA, USA. (Climatology, 8).

Tittonell, P.; Shepherd, K.D.; Vanlauwe, B.; Giller, K.E. 2008. Unravelling the effects of soil and crop management on maize productivity in smallholder agricultural systems of western Kenya: an application of classification and regression tree analysis. Agriculture, Ecosystems \& Environment 123: 137150.

Waskom, R.M.; Westfall, D.G.; Spellman, D.E.; Soltanpour, P.N. 1996. Monitoring nitrogen status of corn with portable chlorophyll meter. Communications in Soil Science and Plant Analysis 27: 545-560.

Yan, P.; Yue, S.; Qiu, M.; Chen, X.; Cui, Z.; Chen, F. 2014. Using maize hybrids and in-season nitrogen management to improve grain yield and grain nitrogen concentrations. Field Crops Research 166: 38-45.

Zaidi, P.H.; Srinivasan, G.; Cordova, H.S.; Sanchez, C. 2004. Gains from improvement for mid-season drought tolerance in tropical maize (Zea mays L.). Field Crops Research 89: 135152. 